\title{
CLINICAL AND LABORATORIAL CHARACTERISTICS OF THE LIVER IN AGED AND NON-AGED ALCOHOLICS
}

\section{Paulo Borini}

Docente (Mestre) da Faculdade de Medicina e Enfermagem de Marília, SP, Brasil.

\section{Romeu Cardoso Guimarães}

Laboratory of Biodiversity and Molecular Evolution, Institute of Biological Sciences, Universidade Federal de Minas Gerais,UFMG-ICB-LBEM, Belo Horizonte (MG), Brasil.

\section{Zamir Calamita}

Docente, Faculdade de Medicina de Marília. Marília, SP, Brasil

Alcoholism. Alcoholics. Fisical examination. Liver. Clinical Enzyme Tests. Healt Services for the Aged

Autor correspondente

Paulo Borini

pb12122@unimedmarilia.com.br

\begin{abstract}
The medical bibliography is deficient in research involving structural and laboratory abnormalities of the liver in asymptomatic and oligosymptomatic male alcoholics. The present study describes the alterations in tests that evaluate liver aggression, lesion and dysfunction, also correlating these with the changes in the consistency and sensitivity of the liver in aged and non-aged alcoholics. Cross-sectional study involving 100 alcoholic men, 50 aged and 50 non-aged. Of the aged and non-aged, respectively, the liver was palpable in $68 \%$ and $80 \%$, the spleen was percutable in $72 \%$ and $74 \%$ and palpable in $12 \%$ and $22 \%$, non-painful soft hepatomegaly was observed in $14 \%$ and $8 \%$, painful hepatomegaly in $0 \%$ and $2 \%$, firm hepatomegaly (painful and nonpainful) in $54 \%$ and $70 \%$, hepatomegaly and splenomegaly (percutable and palpable spleen) in $84 \%$ and $84 \%$, and portal hypertension in $10 \%$ and $14 \%$. Elevated levels of aspartate aminotransferase were observed in $66 \%$ and $84 \%$, alanine aminotransferase in $24 \%$ and $60 \%$, gamma glutamyl transferase in $46 \%$ and $82 \%$ and alkaline phosphatase in $0 \%$ and $16 \%$ of the aged and non-aged, respectively. Elevation of aspartate aminotransferase greater than twice the reference value and the ratio aspartate aminotransferase to alanine aminotransferase greater than 2 were observed in $18 \%$ and $42 \%$ and $18 \%$ and $10 \%$ of the aged and nonaged, respectively. Hypoalbuminemia and hyperbilirubinemia were observed in $70 \%$ and $24 \%$ of the aged and $40 \%$ and $44 \%$ of the nonaged, respectively. The clinical and laboratory alterations observed are compatible with acute liver disease in $18 \%$ and $42 \%$; chronic liver disease in $54 \%$ and $70 \%$; portal hypertension in $10 \%$ and $14 \%$ of aged and non-aged patients, respectively.
\end{abstract}

KEY WORDS: Alcoholics; Liver; Health Services for the Aged.

\section{CARACTERÍSTICAS CLÍNICAS E LABORATORIAIS DO FÍGADO EM ALCOOLISTAS IDOSOS E NẪO IDOSOS}

RESUMO: A bibliografia médica carece de pesquisas que envolvem anormalidades estruturais e laboratoriais do fígado em homens alcoolistas assintomáticos e oligossintomáticos. O presente estudo descreve as alterações de testes que avaliam a agressão, lesão e disfunção, correlacionando-as com as mudanças da consistência e sensibilidade do fígado em alcoolistas idosos e não idosos. Este estudo transversal envolve 100 homens alcoolistas, 50 idosos e 50 não idosos. Em idosos e não idosos, respectivamente, o fígado estava palpável em $68 \%$ e $80 \%$, o baço estava percutível em $72 \%$ e $74 \%$ e palpável em $12 \%$ e $22 \%$, hepatomegalia mole dolorosa foi observada em $14 \%$ e $8 \%$, hepatomegalia mole não dolorosa em $0 \%$ e $2 \%$, hepatomegalia firme (dolorosa e não dolorosa) em 54\% e 70\%, hepatomegalia e esplenomegalia (baço percutível e palpável) em $84 \%$ e $84 \%$ e hipertensão portal em $10 \%$ e $14 \%$. Foram observados níveis elevados da aspartato aminotransferase em 66\% e 84\%, da alanino aminotransferase em $24 \%$ 
e $60 \%$, da gamaglutamiltransferase em $46 \%$ e $82 \%$ e da fosfatase alcalina em $0 \%$ e $16 \%$ dos idosos e não idosos, respectivamente. Foi observada a elevação da aspartato aminotransferase maior que duas vezes o valor de referência e a relação aspartato aminotransferase sobre alanino aminotransferase maior que 2 , em $18 \%$ e $42 \%$ e $18 \%$ e $10 \%$ dos idosos e não idosos, respectivamente. Hipoalbuminemia e hiperbilirrubinemia ocorreram em $70 \%$ e $24 \%$ dos idosos e $44 \%$ e $30 \%$ dos não idosos, respectivamente. As alterações clínicas e laboratoriais observadas são compatíveis com doença aguda do fígado em $18 \%$ e $42 \%$, doença crônica do fígado em $54 \%$ e $70 \%$, hipertensão portal em 10\% e 14\% dos pacientes idosos e não idosos, respectivamente.

PALAVRAS-CHAVE: Alcoólicos; Fígado; Serviços de Saúde para Idosos.

\section{INTRODUCTION}

Some aspects and characters of alcoholism and of the alcoholics are universal while other may differ between groups in consequence of the interaction among factors that influence of each of the aspects of installation of the alcohol abuse habit. It becomes necessary, consequently, to compare individualized populations to enrich the analyses of the patterns of alcoholism and of the clinical and laboratory changes determined by chronic alcohol abuse. The World Health Organization (WHO) estimates that 2 billion people worldwide consume alcohol and that 76.3 million have alcohol-related illnesses ${ }^{1}$. In Brazil, $12 \%$ to $15 \%$ of adult males are dependent on alcohol ${ }^{2}$ and the per capita consumption of alcoholic beverages has increased ${ }^{3,4}$.

The World Health Organization (WHO) classifies as aged, in developing countries, individuals higher than 60 years of age ${ }^{5}$. The fraction of aged in the Brazilian population has grown from $4.8 \%$ in 1991 to $5.8 \%$ in 2000 and $7.4 \%$ in $2010^{6}$. In a survey conducted by the Institute of Psychiatry of the Hospital of the Clinics of São Paulo, it was found that $9.1 \%$ of the aged individuals abused alcohol and, in Brazil the rate of alcoholism among aged men is about $20 \%^{3}$. It is known that there are differences in the patterns of alcoholism according to the age segments, especially between the aged and non-aged groups ${ }^{7}$.

Workers in Brazilian institutions dedicated to the care of abusers of alcohol have observed an increase in the prevalence of alcohol dependency among the aged, the reasons for this being varied ${ }^{8}$. While the aged present lower rates of problems related to alcoholism than the young, around $6 \%$ to $11 \%$ of aged patients admitted in hospitals show manifestations of alcohol dependency. In the rest home the rates of alcoholism rise to $49 \%$. The significant increase in lifetime expectancy among Brazilians is accompanied by a proportional rise in the need for care of aged alcoholics. It is observed that individuals, in the 'third age', which already consumed alcohol at younger ages increased the consumption, as well as others that did not use to consume it, engaged in the regular consumption. It is admitted that the main triggers for the initiation or the increase in alcohol usage would be the installation of loneliness and of inactivity regimes, depressive mood and the sensations of losses and abandonment ${ }^{3}$. The pleasure or the absence of displeasure propitiated by some alcohol usage regimes would be motive forces to induce and install the habit of searching for alcohol or psychoactive drugs ${ }^{10}$.

It is presently established that alcohol is the most important factor, together with nutritional deficiencies following low food ingestion and inadequate uptake and metabolism of nutrients, in causing the various structural, functional and metabolic liver alterations ${ }^{11-14}$.

It is most common in studies evaluating the clinical and laboratorial disturbances occurring in chronic alcoholics the utilization of patient samples with exuberant clinical manifestations. Studies are scarce involving patients in stages where the clinical manifestations are absent or very discrete.

We are living a period in medicine where technology infiltrates the most varied aspects of medical science and it is important to rescue the medical semiotic arts and discuss the problems that occur when searching for diagnoses through laboratory and imaging examinations to the detriment of clinical examination. The present study describes the alterations in tests that evaluate liver aggression, lesion and dysfunction, also correlating these with the changes in the consistency and sensitivity of the liver. 


\section{MATERIAL AND METHODS}

I - PATIENT GROUPS

In this cross-sectional observational analytical study the patients were forwarded from the First Attendance and Screening Center of the city clinics hospital. They were submitted to medical exams and considered apt for psychiatric treatment under hospital admittance regime (Hospital Espírita de Marília - HEM).

Two groups were completed in the period between January 2014 - July 2015, 50 in each of the aged and non-aged.

At admittance, patients answered questions in a structured form sheet (availabre upon request) dedicated to the collection of demographic, psychiatric and clinical data, plus the alcoholism pattern. They were submitted to clinical examination, always by the same physician and inside the first 24 hours from hospitalization.

A blood sample was collected from a vein of an upper member for determination of laboratory parameters. Patients were inside the first 24 hours of internship and under at least 8 hours fast. Exams included: hemogram (hematimetric), aspartate and alanine aminotransferases (automated kinetic-UV), Total bilirrubin and fractions (colorimetric), gamma glutamyl transferase (enzimatic), alkaline phosphatase (enzimatic), total and fractions of proteins (colorimetric), serum amylase (enzimatic), blood glucose (enzymatic, colorimetric) and immunologic markers of hepatitis $\mathrm{B}$ (HBsAg) and C (antibody anti-HCV) viruses of human immunodeficiency virus (antibody anti-HIV) by (HBsAG, AntiHCV e AntiHIV by AntiHBs, AntiHCV and AntiHIV G2ElecsysE2G300, Roche), and syphilis serology (flocculation - Venereal Disease Research Laboratory).

Coproparasitologic examinations were negative for Schistosoma mansoni eggs.

The nutritional status of the patients was evaluated through the Quetelet index of Weight in $\mathrm{Kg} /$ Height in meters ${ }^{2,15}$. The amount of alcohol ingested (in grams, g) per day was calculated through the equation: daily volume of the distilled drink taken in (milliliters, $\mathrm{ml}) \mathrm{x}$ percent (\%) of alcohol in the drink $\mathrm{x}$ density of alcohol (0.8) / 100. The amount of alcohol in $100 \mathrm{ml}$ of the Brazilian sugarcane liquor varies between 40 and 43 grams $^{16}$.

The patients included were alcoholics older than 18 years, satisfying the alcoholism criteria of the International Disease Code (CID 10). Patients not satisfying one of the following criteria were excluded: not consenting to participate, not having complete documentation, presenting indications of mental deficiency, showing delirium tremens, with manifestations considered as indicators of cardiac, hepatic or renal insufficiency, using illicit drugs or medications that can modify the values of the variables under study.

Patients were duly informed on the objectives of the study and gave their consent for participating in it through filling and signing the Term of Free and Clarified Consent (TFCC). Privacy with respect to names and confidentiality were guaranteed to them, as well as all the norms of the Helsinki Declaration. This study was approved by the Ethics Committee, CAAE: 27564714.1.0000.5413 - Opinion substantiated of CEP: 626.044 (Faculdade de Medicina de Marília - SP).

Continuous variables were presented as averages and standard deviation. Statistical comparisons utilized the chi-squared and the Student t-test, at the 5\% significance level.

\section{RESULTS}

Average age of patients in the aged group was 64.7 years and in the non-aged group was 47 years; this mode of preparing the groups promoted statistical significance $(p=0.001)$. Correlated data were the higher prevalence of patients with a job among the non-aged ( $p$ $=0.006)$, the higher prevalence of retired in the aged $(\mathrm{p}$ $=0.001)$, and the higher average salary among the nonaged $(\mathrm{p}=0.023)($ Table 1$)$.

The difference between average ages of starting alcohol usage in the groups was not significant. Average duration of alcohol consumption was higher among the aged $(p=0.001)$ while the daily amount consumed was higher in the non-aged $(p=0.001)$. There was a trend towards reducing the amount of alcohol consumed per day with age inside the aged group. Starting from 40 years of consumption, there was a reduction of the amounts 
consumed in both groups (equally $\mathrm{p}=0.04$ ). Prevalence of tobacco smoking was similar in both groups (Table 2).

When the palpated liver was painless, either soft or firm, the duration of consumption was higher among the aged ( $p=0.001$ in both cases). The duration of consumption was higher among the aged in all cases where the liver was soft and painless, firm and painless, or non-palpable ( $p=0.001$ for all comparisons). The daily consumption was higher among the non-aged when the liver was non-palpable $(p=0.022)$ and when the liver was firm and painless $(p=0.001)$. Prevalence of firm and painless liver was higher than all other categories of liver palpation states in both groups (equally $\mathrm{p}=0.001$ ). (Table 3)

Prevalence of palpable and enlarged as measuredby-percussion spleen, and the palpation characters of organ did not show differences between the groups. The rates of hepatosplenomegaly, including the palpable and measured-by-percussion spleen, were similar in the groups, as well as the association between firm liver and spleen, which are suggestive of portal vein hypertension (Table 4).

Average albumin level was lower than the reference value in both groups $(\mathrm{p}=0.001)$ but the rate of hypoalbuminemia was lower among the aged than the non-aged $(p=0.001)$. Average globulin value was above the normal limit in both groups but significantly so only among the aged $(p=0.019)$.

Average values of aspartate aminotransferase (AST) activities were elevated in both groups, reaching significance in the non-aged group $(\mathrm{p}=0.008)$. Average values of alanine aminotransferase (ALT) were elevated only in the non-aged group, the difference being significant $(p=0.004)$. The rates of elevated aspartate aminotransferase did not differ between groups while the rate of elevated alanine aminotransferase was higher in the non-aged group $(p=0.005)$. The rate of AST higher than twice the normal upper limit was higher among the non-aged $(p=0,027)$; individuals with this condition were $58 \%$ in the group. There was no difference in the rate of the elevated $(>2)$ AST/ALT ratio between the groups, the individuals with that condition being $28 \%$ in the total sample (18\% in the aged, $10 \%$ in the non-aged).

Average alkaline phosphatase levels were in the normal range in both groups but, comparing the two groups, both the average value and the rate of elevated values were higher in the non-aged group ( $p=0.001$ and $p=0.024$, respectively). Average values of gamma glutamyl transferase were higher than normal in both groups $(p=0.004)$, but the rate of elevations was higher in the non-aged group $(\mathrm{p}=0,001)$. Association of elevated rates of alkaline phosphatase and gamma glutamyl transferase occurred significantly among the non-aged patients $(\mathrm{p}=0.035)$.

There was no significant difference in the prevalence of elevated serum amylase among the aged (2\%) and non-aged (12\%). Average amylase values were in the normal range but the levels were higher among the non-aged $(p=0,003)$. (Table 5$)$

The rates of appearance of lowered serum albumin (below $3.5 \mathrm{~g} \%$ ) were higher when the liver was palpable than non-palpable, in both groups (aged $\mathrm{p}=$ 0.04 , non-aged $p=0.002$ ). The rate of hypoalbuminemia was higher when the palpated liver was firm and painless $(p=0.002)$. The prevalence of elevated total bilirubin was higher when the liver was palpable than non-palpable, the difference showing up only among the non-aged ( $p$ $=0.03$ ) (Table 6)

The frequencies of positive serologic reactions for hepatitis B virus (HBV), hepatitis C virus (HCV), human immunodeficiency virus (HIV), and syphilis were similar in both groups, as well as the frequency of tattooed patients (Table 7).

\section{DISCUSSION}

It is common that the alcoholic does not get fed adequately due to the caloric value of alcohol. The quantity of calories in the drinks are enough to substitute an important fraction of what should be derived from the dietary components, leading to the reduction of the necessity of ingesting food ${ }^{17}$. Inadequate ingestion of proteins and other nutrients is an important factor in the generation of liver lesion ${ }^{14}$. Concomitantly, hepatocyte lesion is accompanied by reduction in the synthesis of proteins and other substances. ${ }^{11}$ The outcome is the establishment of a vicious cycle where liver dysfunction is accentuated. 
In countries in development, especially among the less favored economic strata, undernourishment is a relatively common occurrence, independently from alcoholism, to the point of not making observable some statistically significant difference in the degrees of undernourishment between alcoholics and nonalcoholics $^{18}$. A possible explanation for such observation would be that the malnutrition does not show up more intensely among alcoholics in consequence of their frequent hospitalizations motivated by a greater frequency of alcoholic intoxication due to a reduction of the metabolic tolerance ${ }^{7,19}$.During the periods of hospitalization there is an interruption of alcohol consumption, improvement in quality and quantity of feeding and correction in vitamin deficiencies, which allow for recovery of nutritional deficiencies of many patients. The nutritional condition of patients in this study was considered good to regular in $100 \%$ to $86 \%$ of them, in the respective groups of aged and non-aged ${ }^{15}$. The average values of the Body Mass Index were located inside the healthy category. Only $10 \%$ of the aged and $4 \%$ of the non-aged were underweight.

It is inside the socioeconomically less privileged strata of populations that the most intense and more widespread rates of alcoholism are observed ${ }^{20}$. According to this, patients forming our study groups belonged to the strata D (29\%) and E (71\%), with low income and school attendance rate. Some studies question the influence of school attendance effects. It is admitted that some of these inconsistencies would reflect systematic biases that are common in field studies and may be intensified according to the kinds of populations studied ${ }^{21}$.

The most commonly cited risk factors for liver alcoholic disease are age, age at starting the use, duration of the usage, pattern of drinking, gender, obesity, dietary and genetic factors, tobacco smoking habit ${ }^{22}$. With respect to age, in Brazil, there is a new demographic pattern transforming the age structure with a significant increase in the aged component, but it is possible that there might be local or temporal fluctuations in this trend ${ }^{23}$. The number of aged patients admitted into the psychiatric hospital where our study was installed has not varied significantly in the last 5 years $^{24}$.

The age at the start of alcohol usage was similar in the aged and non-aged groups. As expected, the average duration of the consumption was longer among the aged. The average daily consumption of alcohol was higher among the non-aged. In both groups, after 39 years of the habit, there was a trend towards reduction of the daily consumption. This reduction in consumption, also described by Parry ${ }^{19}$, had already been observed in a previous study carried out with patients hospitalized at the same hospital ${ }^{24}$. It suggests a reduction in alcohol tolerance due to the involvement of operant and classical conditions (Pavlovian) and interactions between neurotransmitter systems ${ }^{25}$. It could also be related to clinical conditions, physical symptoms, medication use and marked liver functional change, which is not the case of the aged in this study. In a longitudinal study conducted in the United States of America (USA), it was verified that the decline in heavy alcohol use with the age was not associated with cohort effects ${ }^{26}$.

In studies involving patients with clinical characters similar to the chronic alcoholics in this, it was observed that $82 \%$ of the patients presented histologic alteration ${ }^{27}$ while evidence of necrosis or fibrosis were present in $40 \%-50 \%$ of them. ${ }^{28,29}$ Liver histologic lesions of steatosis, hepatitis or cirrhosis may be associated in the same individual with variable intensities; furthermore, any one of them, in isolation or in association, may cause metabolic alteration via liver dysfunction ${ }^{14}$. On another side, it should be considered that alcoholics, even with minimal liver damage, may present abnormalities in pancreatic function, with reduction in enzyme production and consequent disturbance in digestion and absorption of nutrients ${ }^{30}$.

Considering that liver biopsy in asymptomatic or oligosymptomatic alcoholics, besides involving ethical problems, does not find receptivity by patients who do not consider themselves sick, the characterization of the type of liver lesion was limited to the palpation characteristics of the liver. Increases in liver dimensions may occur in the absence of liver lesion, as well as it may occur that a damaged liver may not be palpable. A diminished consistency of the liver at palpation (soft liver) is observed in acute congestion, fatty infiltration and in acute inflammatory processes. An accentuated consistency (firm liver, not necessarily hard) occurs in 
processes that determine liver fibrosis. A painful liver is related to the presence of inflammatory process, usually acute ${ }^{31-33}$. Presence of splenomegaly was evaluated by both palpation and percussion, according to the procedure of Battlo et al. ${ }^{31}$ In the alcoholic, the soft spleen may result from acute alcoholic hepatitis, while the firm spleen appears when portal hypertension is installed ${ }^{31}$.

It should be considered that the hepatic alterations representative of steatosis, inflammation and fibrosis are not mutually exclusive and some of them may overlap, occurring in different degrees of intensity and simultaneously in the same patient. ${ }^{34}$ Correlations have been found between histopathology and hepatic semiology ${ }^{35,36}$, serum biochemistry ${ }^{10,36,37}$ and associations of clinical and biochemical data ${ }^{11,36,38}$. and the clinical, biochemical and diagnostic data associations ${ }^{39,40}$.

In studies with liver histopathology, 25\%-35\% of chronic alcoholics with mild or no clinical manifestation of hepatopathy were considered free of liver disease $\mathrm{e}^{27,41}$. In the present study, the liver was not palpable in $32 \%$ and $20 \%$ of the elderly and non-elderly patients, respectively.

Some degree of liver steatosis is present in about $90 \%$ of alcoholics ${ }^{28,38}$. The sample in our study showed soft liver, painful or not, which are characters of fatty liver, with or without inflammation, in $24 \%$ of patients, distributed in the aged (14\%) and non-aged (10\%). This frequency is close to the $20 \%$ of Mann ${ }^{42}$ and $28 \%$ of Nakamura ${ }^{43}$, above that observed by Brunt $(9 \%)^{44}$ and Green $(11 \%)^{45}$ and far below Mezey $^{17}$ (56\%) and Harinasuta ${ }^{46}(61 \%)$. The large variation in the prevalence of steatosis between studies may have come from the nutritional state of the individuals in the samples, the degree and duration of the habit, plus constitutional and other environmental factors. In the present study, some bias might have been introduced together with the age selection in the composition of the sample.

Alcoholic hepatitis usually follows the sudden increase in daily intake by the alcoholic, which lasts for some time. In asymptomatic or oligosymptomatic alcoholics, the prevalence of acute hepatitis ranged from $13.5 \%{ }^{43}, 24.5 \%{ }^{45}$ and $38.9 \%{ }^{46}$. According to Schenker ${ }^{29}$, the prevalence of acute hepatitis in alcoholics varied from $8 \%$ to $63 \%$ in previous studies. Indicators of probable acute inflammation are soft and painful hepatomegaly together with elevation of AST (aspartate aminotransferase) at 2 to 6-fold the upper normal limit ${ }^{22,38,39}$. In our study, the AST elevation to 2 -fold or higher than the reference value was observed in $12 \%$ of the aged and $28 \%$ of the non-aged, totaling $40 \%$ of the patients that, with a high probability, were under acute hepatitis at the time of examination. Other study indicated that a further $40 \%$ fraction of the acute hepatitis patients would develop cirrhosis if they continue with the heavy alcohol drinking ${ }^{42}$.

In Brazil, between $12 \%$ and $30 \%$ of alcoholics develop cirrhosis. ${ }^{47}$ When the liver cirrhosis state is reached, the AST/ALT ratio becomes lower than 2 in consequence of greater elevation of $\mathrm{ALT}^{12,13}$. In our sample there was a high proportion of the ratio AST/ALT lower than 2. Firm hepatomegaly, painful or not, which indicates liver fibrosis occurred in $54 \%$ of the aged and in $70 \%$ of the non-aged (average 62\%). The 5 year survival rate of cirrhotic individuals that stop drinking is $90 \%$, compared to $70 \%$ among those that continue drinking ${ }^{48}$. In the last stages of the progression of the cirrhotic state, when icterus, ascites or gastrointestinal hemorrhage enter the picture, the survival rate becomes $60 \%$ among those stopping the drinking and only $35 \%$ among those continuing the habit ${ }^{42}$.

The combination of elevated total bilirubin, alkaline phosphatase and gammaglutamyltransferase (GGT), which is suggestive of cholestasis, was observed only among the non-aged patients (8\%). No references were found in the literature on the prevalence of cholestasis in alcoholic liver disease.

It is highlighted that we were careful to exclude the possibility that alterations of liver enzymes, especially the aminotransferases, would have been due to comorbidities such as overweight and obesity, dyslipidemia, non-alcoholic steatohepatitis, infection by hepatitis B or C, syphilis, congestive cardiac insufficiency, anemia or the use of medicines or illicit drugs.

Different rates of hypoalbuminemia and hyperbilirubinemia were observed in both groups, independently of the presence or absence of hepatomegaly. The observation indicates that liver function is already compromised when the organ is not yet palpable. Greater frequency of hypoalbuminemia occurred when the organ was firm and not painful, indicating that fibrosis-settling factors are correlated with albumin synthesis-impairing factors. 
Hepatomegaly individuals presented hyperbilirubinemia rates higher than those with a non-palpable liver. This is one more indication that liver dysfunction was already present before the liver becomes palpable. Advancing further, it was seen that hepatosplenomegaly, expressed as the firm and not painful characteristics of both liver and spleen, was observed in $10 \%$ of the aged and $14 \%$ of the non-aged, which is suggestive of the development of portal venous system hypertension in consequence of the liver fibrosis.

In view of the impossibility, for various reasons already pointed at above, of practicing liver biopsies in the sampled individuals, this observation acquires clinical significance, especially under the evidence of the possibility that fibrosis can be reversible when the patient is still pre-cirrhotic and engages in complete alcohol abstinence ${ }^{48}$.

It was thought for a long time that the metabolic alterations accompanying alcoholism originated from inadequate ingestion or from disturbed digestion or absorption of nutrients. Even the liver lesions have been attributed to nutritional deficiencies. The situation is now established that the metabolic alterations that follow abusive usage of alcoholic beverages are determined mainly by the hepatotoxicity of ethano ${ }^{14}$.

In acute hepatitis, except in very intense or prolonged forms, the levels of plasma proteins either do not vary or vary with small expressiveness. In chronic hepatitis and cirrhosis, in parallel with the intensification of the cellular structural damage, the trend is for decreases in the albumin levels and increase in the globulins, so that the albumin/globulin ratio is inverted from the normal, growing to $>1$ values $^{49}$.

Patients in this study with low albumin levels were $70 \%$ among the aged and $44 \%$ among the nonaged. Considering that only $10 \%$ of the aged and, $4 \%$ of the non-aged were underweight, and that there were no significant differences between the two groups with respect to the palpation characters of liver and spleen, which could be suggestive of chronic liver lesion, we are left with the conjecture that the albumin alteration in the two groups are consequent to dietary problems and not to liver synthesis dysfunction.
In this study, serum amylase elevation, suggestive of pancreatic aggression, was observed in $2 \%$ of the aged and in $12 \%$ of non-aged, and the association of hyperamylasemia and hyperglycemia was observed in $2 \%$ of patients in both groups. The influence of pancreatic impairment on patients' nutritional status requires more precise evaluation.

The frequencies of positive serological reactions for hepatitis B and C, HIV and syphilis were similar in both groups. No information on the frequency of hepatitis B, $\mathrm{C}$ and HIV and, tattooed in alcoholics was found in the Brazilian studies. Regarding syphilis, the positive reaction rate observed in 200 alcoholics admitted to the same hospital (Hospital Espírita de Marília) where this study was performed was $6.3 \%$, similar to the rate of the aged and lower than that of the non-aged50. The frequency of tattooed patients is of interest to the physician since it may be parenteral route of entry for hepatitis B and C virus.

\section{CONCLUSION}

The clinical and laboratorial alterations observed are compatible with acute liver disease in 18\% and $42 \%$, chronic liver disease in $54 \%$ and $70 \%$ and portal hypertension in $10 \%$ and $14 \%$ of the aged and non-aged patients, respectively.

This study contributed with mainly some baseline clinical data, mainly due to the sample characteristics, of male adults and male aged with scarce symptoms and signs, admitted into a psychiatric hospital for treatment of intoxication episodes. It is expected that the question form we developed for collection and examination of the clinical and laboratory data will be found useful for further studies in other samples.

\section{REFERENCES}

1. World Health Organization. Global Status Report Health Geneve.Department of Mental Health and Substance Abuse; 2011.

2. Borini P, Silva CO. Aspectos demográficos, epidemiológicos e sociais do alcoolismo: uma análise de alcoolistas internados em hospital psiquiátrico. Rev ABP-APAL.1989; 11(3);89-96. 
3. Laranjeira R, Pinsky I, Zaleski M, Caetano R. I Levantamento nacional sobre padrões de consumo de álcool na população brasileira. Brasília (DF): Secretaria Nacional Antidrogas (SNAD) 2007.

4. INCT - Instituto Nacional de Ciência e Tecnologia para Políticas Públicas do Álcool e outras Drogas. Levantamento Nacional de Álcool e drogas (LEAD 2012). Brasilia (DF): INPAD; 2012.

5. World Health Organization, 2005. Envelhecimento ativo: uma política de saúde. Brasília. Organização Pan-Americana de Saúde.

6. IBGE - Instituto Brasileiro de Geografia e Estatística (IBGE). Censo demográfico (Brasil e Estados): recenseamento geral do Brasil, 2010. Rio de Janeiro, 2011).

7. Borini P, Cleusa OS. Análise de alguns aspectos do padrão de alcoolismo e suas implicações terapêuticas. Rev ABP-APAL. 1991; 13(3):105-11

8. Organização Mundial da Saúde. Relatório global sobre álcool e saúde: 2014 [Internet]. Genebra; 2014. [citado em 10 jan 2016]. Disponível em: http://www.cisa.org.br/artigo/4429/relatorio-globalsobre-alcool-saude-2014.php

9. Edwards G, Marshall EJ, Cook CC. A sindrome da dependência de álcool. In: Edwards G, Marshall EJ, Cook CC eds. O tratamento do alcoolismo: um guia para profissionais da saúde. 4. ed. Porto Alegre (RS): Armed; 2005. p. 55-71.

10. Sanchez-Craig M, Israek Y. Pattern of alcohol consumption associated with self-identified problem drinking. Am J Pub Health. 1985: 75(2):178-80.

11. Borini P, Guimarães RC. Noninvasive classification of liver disease in asymptomatic and oligosymptomatic male alcoholics. Braz J Med Biol Res. 2003;36(10):1367-73

12. Sherlock S, Dooley J. Alcohol and the liver. In: Diseases of the liver and biliary system, $9^{\mathrm{a} e d}$. London (GB): Blackwell Scientific Publications, 1993. p. 370-89.

13. Diehl AM. Doença hepática alcoólica. Clínicas Médicas da América do Norte, 1989; 4(1):889-917.

14. Lieber CS. O metabolismo e os efeitos metabólicos do álcool. Clin Med Am Norte. 1984;1:3-33.

15. Anjos LA. Índice de massa corporal (massa corporal. estatura ${ }^{2}$ ) como indicador do estado nutricional de adultos: revisão de literatura*. Rev Saúde Publ, São Paulo. 1992;26(6):431-6.

16. Brasil. Ministério da Agricultura, Pecuária e Abastecimento. Instrução Normativa $n^{0}$ 13/2005. Diário Oficial da União 30/06/2005.

17. Mezey E, Santora BB. Liver abnormalities in alcoholism: alcohol consumption and nutrition. In: Gastineau CF, Darby WJ, Turner TB, eds. Fermented food beverages in nutrition. New York (EEUU): Academic Press; 1979.

18. Sadeck MGA, Sigulem DM. Alcoolismo e estado nutricional proteico calórico. VIII Congresso Brasileiro de Alcoolismo. São Paulo, Brasil. 1989.

19. Parry RA. Alcoholism and drug misuse. In: Forrest A, editor. Companion to psychiatric studies. Edinburgh and London (RU): Churchill Livingstone; 1973. p. 116-37.

20. Gigante LP. Alcoolismo e uso de álcool. Relação com o perfil socioeconômico de adultos residentes em Porto Alegre [dissertação]. Porto Alegre (RG): Universidade Federal do Rio Grande do Sul; 1988

21. Edwards G, Marshall EJ, Cook CC. Causas dos problemas relacionados ao consumo de álcool. In: Edwards G, Marshall EJ, Cook CC eds. O Tratamento do alcoolismo: um guia para profissionais da Saúde. 4. ed. Porto Alegre (RS): Artmed; 2005. p. 29-39.

22. Prado V, Caballeria J, Vargas V, Bataller R, Altamirano J. Alcoholic hepatitis: how far are we and were are we going. Ann Hepatol. 2016;15(4):463-74.

23. Veras RP. Brazil is getting older: demographic changes and epidemiological challenges. Rev. Saúde Públ. 1991;25(6):476-88.

24. Borini P, Silva CO. Tratamento de alcoolistas em regime de internação hospitalar: avaliação de resultados. J Bras Psiquiatr. 1993;47(3):149-55.

25. Edwards G, Marshall EJ, Cook CC. O álcool como droga. In: Edwards G, Marshall EJ, Cook CC. O tratamento do alcoolismo: um guia para profissionais da Saúde, 4. ed. Porto Alegre (RS): Artmed; 2005. p. 41-53.

26. Karlamangla A, Zhou K, Reuben D, Greendale $\mathrm{G}$, Moore A. Longitudinal in trajectories of heavy drinking in adults in the Unites States of America. Addiction. 2006; 101(1):91-9 
27. Bruguera M, Bordas JM, Rodés J. Asymptomatic liver diseases in alcoholics. Arch Pathol Lab Med 1977;101(12):644-7.

28. Diehl AM. Liver disease in alchol abusers: clinical perspective. Alcohol. 2002;27(1):7-11.

29. Schenker S. Alcoholic liver disease: evaluation of natural history and prognostic factors. Hepatology. 1984;4(1):36S-43S.

30. Mezey E, Potter JJ. Changes in exocrine pancreatic function produced by altered dietary protein intake in drinking alcoholics. John Hopkins Med J 1975; 138:7-12.

31. Battlo AS. Aparelho digestivo - fígado e baço. In: Semiologia Médica \& Técnica exploratória, $6^{\mathrm{a}}$ ed. Forns JS, Battlo JS, Battlo AS eds. Rio de Janeiro: Editora Guanabara Koogan, 1981. p. 394-438.

32. Vieira R Romero - Semiologia Médica. Coordenação Affonso Berardinelli Tarantino; vol 2. $2^{\mathrm{a}}$ ed. Rio de Janeiro: Editora Guanabara Koogan, 1980. p. 41213.

33. Dani R, Castro LP, Perez V, Arabehety JT. Gastroenterologia. Rio de Janeiro: Editora Guanabara Koogan, 1978. P. 626-46.

34. Fleming KA, McGee JO. Alcohol Induced liver disease. J Clin Pathology. 1984;37(7):721-33.

35. Sherlock S, Dooley J. Assessment of liver function. In: Sherlock S, Dooley J eds. Diseases of the liver and biliary system, $9^{\mathrm{a}}$ ed. London (GB): Blackwell Scientific Publications, 1993. p. 17-32 and 370-89.

36. Oberti F, Valsesia E, Pilette C, Rousselet MC, Bedosa P, Aubê C, Gallois Y, Rifflet H, Maiga MY. Noninvasive diagnosis of hepatic fibrosis or cirrosis. Gastroenterology. 1997;113(5):1609-16.

37. Poynard T, Aubert A, Bedosa P, Abelia A, Naveau S, Paraf F, Chaput JC, Benhamou JP. A simple biological index for detection of alcoholic liver disease in drinkers. Gastroenterology. 1991; 100(5 PEI):1397-402.

38. Borini P. Avaliação do envolvimento hepático em alcoolistas crônicos assinstomáticos ou oligossintomáticos. 2. Aspectos laboratoriais. GED Gastr Endos Dig. 1991:10(4):137-43.

39. Mincis M. Hepatite alcoólica. RBM - Rev Bras Med. 2003;60(11):828-48.
40. Tsurusaki M, Semelka RC, Zapparoli M, Elias Jr. J, Altun E, Pamuklar E, Sugmura K. Quantitative and qualitative comparison of $3.0 \mathrm{~T}$ and $1.5 \mathrm{~T}$ MR imaging of the liver in patients with diffuse parenchymal liver disease. Eur J Radiol. 2009; 72(2):314-20.

41. Pimstone NR, French SW. Hepatopatia alcoólica. In: Geokas MC. Álcool etílico e enfermidades associadas. Clin Med Am Norte. 1984; 1:43-61.

42. Mann RE, Smart RG, Govoni R. The epidemiology of alcoholic liver disease. Alcohol Res Health. 2003; 27(3):209-319.

43. Nakamura T, Nakamura S, Suzuki O, Aikawa T, Onodera A, Karoji N. Clinical studies of alcoholic hepatic diseases. Tohoku J Exp Med. 1967;93(2):179-89

44. Brunt PW, Kew MC, Scheurer PT, Sherlock S. Studies in alcoholic liver disease in Britain. Gut. 1974; 15(1):52-8.

45. Green JR. Subclinical acute liver disease of alcoholic. Australas Ann Med. 1965;14:111-24.

46. Harinasuta U, Zimmerman HJ. Alcoholic steatonecrosis. I. Relationship between severity of hepatic disease and Mallory bodies in the liver. Gastroenterology. 1971;60(6):1036-46.

47. Mincis M. Inquerito Nacional sobre Doença Hepática Alcoólica. In: $11^{\circ}$ Congresso Nacional de Hepatologia \& Jornada Latino-Americana Extra de Hepatologia; 3-6 abr 1991; Foz do Iguaçu, Brasil. 1991.

48. Pinzani M, Rosseli M, Zuckerman M. Liver cirrhosis. Best Pract Res Clin Gastroenterol 2011; 25(2):28190.

49. Mincis M. Hepatotologia clínica e cirúrgica. São Paulo: Sarvier; 1986. p. 563-67.

50. Borini P. Alcoolismo e sífilis: prevalência e alterações clínicas e bioquímicas hepáticas. Rev Inst Med Trp São Paulo. 1993; 35(3):219-25.

Recebido em: 23/03/2019

Aceito em: 06/09/2019 
Table 1. Demographic aspects of aged and non-aged alcoholics adimitted to the Hosptial Espírita de Marília - HEM from 01/2014 to $07 / 2015$

\begin{tabular}{|c|c|c|c|}
\hline & Aged & Non-aged & \\
\hline & $\geq 60$ years & $<60$ years & $\mathrm{p}$ \\
\hline Number of patients & 50 & 50 & \\
\hline Average age & $64,7 \pm 5,3$ & $47,0 \pm 9,9$ & 0,001 \\
\hline \multicolumn{4}{|l|}{ Civil status } \\
\hline Married & $17(34 \%)$ & $8(16 \%)$ & 0,060 \\
\hline Single & $11(22 \%)$ & $18(36 \%)$ & 0,186 \\
\hline Separated & $6(12 \%)$ & $11(22 \%)$ & 0,286 \\
\hline Divorced & $5(10 \%)$ & $4(8 \%)$ & 1.001 \\
\hline Legally separated & $4(8 \%)$ & $1(2 \%)$ & 0,362 \\
\hline Living to gether & $2(4 \%)$ & $7(14 \%)$ & 0,159 \\
\hline Widower & $5(10 \%)$ & $1(2 \%)$ & 0,204 \\
\hline \multicolumn{4}{|l|}{ Skin color } \\
\hline White & $35(70 \%)$ & $31(62 \%)$ & 0,526 \\
\hline Brown & $10(20 \%)$ & $15(30 \%)$ & 0,355 \\
\hline Black & $5(10 \%)$ & $4(8 \%)$ & 1,001 \\
\hline \multicolumn{4}{|l|}{ General condition } \\
\hline Good & $34(68 \%)$ & $40(80 \%)$ & 0,254 \\
\hline Regular & $16(32 \%)$ & $3(6 \%)$ & 0,101 \\
\hline $\mathrm{Bad}$ & - & $2(4 \%)$ & - \\
\hline \multicolumn{4}{|l|}{ Body Mass Index } \\
\hline Average & $23,0 \pm 3,1$ & $22,7 \pm 3,7$ & 0,651 \\
\hline Underweight & $5(10 \%)$ & $2(4 \%)$ & 0,436 \\
\hline Healthy & $29(58 \%)$ & $35(62 \%)$ & 0,297 \\
\hline Overweight & $15(30 \%)$ & $10(20 \%)$ & 0,355 \\
\hline Obese & $1(2 \%)$ & $3(6 \%)$ & 0,617 \\
\hline \multicolumn{4}{|l|}{ Social class } \\
\hline $\mathrm{A}$ and $\mathrm{B}$ & - & . & - \\
\hline $\mathrm{C}$ & - & $2(4 \%)$ & - \\
\hline $\mathrm{D}$ & $4(8 \%)$ & $9(18 \%)$ & 0,234 \\
\hline E & $46(92 \%)$ & $39(78 \%)$ & 0,090 \\
\hline \multicolumn{4}{|l|}{ Labor activity } \\
\hline Yes & $25(50 \%)$ & $42(69 \%)$ & 0,006 \\
\hline Retired & $23(46 \%)$ & $1(4 \%)$ & 0,001 \\
\hline No & $2(14 \%)$ & $5(5 \%)$ & 0,436 \\
\hline Pension (ISS) & 0 & $2(8 \%)$ & 0,494 \\
\hline Average income (Brazilian R\$) & $747 \pm 413$ & $1082 \pm 943$ & 0,023 \\
\hline
\end{tabular}


Table 2. Pattern of alcoholism of aged and non-aged patients adimitted to the Hospital Espírita de Marília - HEM from 01/2014 to $07 / 2015$

\begin{tabular}{|c|c|c|c|}
\hline & $\begin{aligned} & \text { Aged } \\
& \geq 60 \text { years } \\
&\end{aligned}$ & $\begin{array}{l}\text { Non-aged } \\
<60 \text { years }\end{array}$ & $\mathrm{p}$ \\
\hline Number of patients & 50 & 50 & \\
\hline Average age at beginning of usage & $21,3 \pm 9,5$ & $20.4 \pm 8,7$ & 0,622 \\
\hline Average duration of consumption (years) & $43,3 \pm 10,0$ & $23,6 \pm 10,7$ & 0,001 \\
\hline Daily consumption (grams) & $503 \pm 390$ & $853 \pm 618$ & 0,001 \\
\hline \multicolumn{4}{|l|}{ Age range (years) and consumption (grams) } \\
\hline 20 to 29 & $\cdot$ & $21080 \pm 1301$ & \\
\hline 30 to 39 & - & $111017 \pm 854$ & \\
\hline 40 to 49 & - & $23912 \pm 474$ & \\
\hline 50 to 59 & - & $14820 \pm 486 *$ & \\
\hline 60 to 69 & $42504 \pm 339 *$ & - & 0,070 \\
\hline 70 to 80 & $8283 \pm 169 *$ & - & 0,004 \\
\hline \multicolumn{4}{|c|}{ Duration of consumption (years) and daily consumption (grams) } \\
\hline$<10$ & $1300 \pm 0$ & $5952 \pm 915$ & - \\
\hline 10 to 19 & 0 & $13722 \pm 539$ & - \\
\hline 20 to 29 & $3567 \pm 379$ & $15909 \pm 641$ & 0,202 \\
\hline 30 to 39 & $5682 \pm 552$ & $131178 \pm 446$ & 0,582 \\
\hline 40 to 49 & $29462 \pm 309$ & $4675 \pm 207^{*}$ & 0,040 \\
\hline 50 to 59 & $10402 \pm 265 *$ & - & 0,001 \\
\hline 60 to 63 & $2456 \pm 260 *$ & - & 0,040 \\
\hline \multicolumn{4}{|l|}{ Tobacco smoking } \\
\hline Yes & $3162 \%$ & $3978 \%$ & 0,126 \\
\hline No & $1938 \%$ & $1122 \%$ & 0,126 \\
\hline
\end{tabular}

* Statistical comparison between cells.

The medians were 22 years and 25 years for aged and non-aged, respectively.

Table 3. Consistency and sensitivity of the liver related to the pattern of alcoholism of aged and non-aged alcoholics

\begin{tabular}{|c|c|c|c|c|c|c|c|c|}
\hline & & Aged & & & Non-aged & & & \multirow[b]{4}{*}{$\mathrm{p}$} \\
\hline & \multicolumn{3}{|c|}{$\geq 60$ years } & \multicolumn{3}{|c|}{$\leq 60$ years } & \multirow[b]{3}{*}{$\mathrm{p}$} & \\
\hline & n. & Duration & Daily use & n. & Duration & Daily use & & \\
\hline & 50 & of use & (g) & 50 & Of use & (g) & & \\
\hline & & (Years) & & & (Years) & & (Time) & (Daily) \\
\hline Liver palpable & $34(68 \%)^{*}$ & $43 \pm 2$ & $460 \pm 114$ & $40(80 \%)^{*}$ & $24 \pm 2$ & $650 \pm 790$ & 0.001 & 0.001 \\
\hline Liver not palpable & $16(32 \%)^{* *}$ & $43 \pm 15$ & $431 \pm 394^{€}$ & $10(20 \%)^{* *}$ & $23 \pm 11$ & $892 \pm 569^{€}$ & 0.001 & 0.022 \\
\hline \multicolumn{9}{|l|}{ Liver palpable } \\
\hline Soft not painful & 7 (14\%) & $43 \pm 4$ & $555 \pm 439$ & $4(8 \%)$ & $22 \pm 9$ & $572 \pm 427$ & 0.001 & 0.001 \\
\hline Soft painful & - & - & - & $1(2 \%)$ & $27 \pm 0$ & $600 \pm 0$ & - & - \\
\hline Firm not painful & $25(50 \%) \uparrow$ & $44 \pm 8$ & $334 \pm 176$ & $25(50 \%) \uparrow$ & $23 \pm 11$ & $683 \pm 447$ & 0.001 & 0.001 \\
\hline Firm painful & $2(4 \%)$ & $41 \pm 1$ & $492 \pm 170$ & $10(20 \%)$ & $22 \pm 13$ & $745 \pm 475$ & 0.075 & 0.485 \\
\hline
\end{tabular}

In both groups, the number of patients with palpable liver* was significantly higher than those with not palpable liver** (p: 0.001$)$. In both groups, the prevalence of firm and not-painful liver was significantly higher than other characteristics of consistency and sensitivity of the liver. The amount of alcohol ingested by the non-aged group was significantly higher when the liver was not palpable ${ }^{\epsilon}$ (p: 0.010) 
Table 4. Splenomegaly in aged and non-aged alcoholics

\begin{tabular}{lccc}
\hline & Aged & Non-Aged & \\
\cline { 2 - 4 } & n. 50 & n. 50 & p \\
\hline Spleen palpable & $6(12 \%)$ & $11(22 \%)$ & 0.287 \\
Soft not painful & $1(2 \%)$ & $3(6 \%)$ & 0.617 \\
Firm not painful & $5(5 \%)$ & $7(14 \%)$ & 0.758 \\
Spleen percutible & $36(72 \%)$ & $37(74 \%)$ & 1.000 \\
Splenomegaly* with hepatomegaly & $42(84 \%)$ & $48(84 \%)$ & 0.095 \\
Portal hypertension ** & $5(10 \%)$ & $7(14 \%)$ & 0.758 \\
\hline
\end{tabular}

* Spleen percutible and palpable. ** Spleen palpable

Table 5. Laboratorial aspects of aged and non-aged alcoholics

\begin{tabular}{|c|c|c|c|}
\hline & Idosos & Não-Idosos & p \\
\hline & $\geq 60$ anos & $<60$ anos & \\
\hline Total proteins (6.5 to $8.0 \mathrm{~g} \%)$ & $6.6 \pm 0.6$ & $6.3 \pm 0.36$ & 1.001 \\
\hline Albumin (3.5 to $4.8 \mathrm{~g} \%)$ & $3.3 \pm 0.3$ & $3.4 \pm 0.3$ & 0.001 \\
\hline Low & $35(70 \%)$ & $20(40 \%)$ & 0.001 \\
\hline Globulin (2.0 to $3.0 \mathrm{~g} \%$ ) & $3.27 \pm 0.44$ & $3.07 \pm 0, .37$ & 0.019 \\
\hline High & $32(64 \%)$ & $27(52 \%)$ & 0.311 \\
\hline Total bilirirubin (up 1.2 mg\%) & $1.05 \pm 0,52$ & $1.11 \pm 0.0,56$ & 0,581 \\
\hline High & $12(24 \%)$ & $15(30 \%)$ & 0.652 \\
\hline Aspartate aminotransferase - AST $(\leq 37 \mathrm{U} / \mathrm{L})$ & $56 \pm 38$ & $99 \pm 105$ & 0.008 \\
\hline High & $33(66 \%)$ & $42(84 \%)$ & 0.065 \\
\hline AST > $74(2 \mathrm{VR})$ & $9(18 \%)$ & $21(42 \%)$ & 0.027 \\
\hline AST $>74$ and palpable liver & $6(12 \%)$ & $14(28 \%)$ & 0.080 \\
\hline Soft and painless liver & $1(2 \%)$ & $2(4 \%)$ & 1.001 \\
\hline Soft and painful liver & - & - & - \\
\hline Firm and painless liver & $4(8 \%)$ & 7 (14\%) & 0.522 \\
\hline Firm and painful liver & $1(2 \%)$ & $5(10 \%)$ & 0.204 \\
\hline Liver not palpable & $3(6 \%)$ & $6(12 \%)$ & 0.486 \\
\hline Alanine aminotransferase - ALT $(\leq 42 \mathrm{U} / \mathrm{L})$ & $41.9 \pm 37.2$ & $80.0 \pm 80,7$ & 0.004 \\
\hline High & $1(24 \%)$ & $30(60 \%)$ & 0.005 \\
\hline AST/ALT > 2 & $9(18 \%)$ & $5(10 \%)$ & 0.387 \\
\hline Alcaline phosphatase - AP $(\leq 270 \mathrm{U} / \mathrm{L})$ & $69.7 \pm 68.6$ & $200.8 \pm 66,0$ & 0.001 \\
\hline High & $0-$ & $6(16 \%)$ & 0.024 \\
\hline Gamaglutamyltransferase - GGT (11 to $50 \mathrm{U} / \mathrm{L}$ ) & $128,0 \pm 184$ & $256 \pm 245$ & 0.004 \\
\hline High & $23(46 \%)$ & $41(82 \%)$ & 0.001 \\
\hline $\mathrm{AP}>270 \mathrm{U} / \mathrm{L}$ and $\mathrm{GGT}>50 \mathrm{U} / \mathrm{L}$ & 0 - & $6(12 \%)$ & 0.035 \\
\hline Amylasemia (60 a 160 UA\%) & $106.0 \pm 23$ & $129.4 \pm 34.4$ & 0.003 \\
\hline High & $1(2 \%)$ & $6(12 \%)$ & 0.117 \\
\hline Amylase > $150 \mathrm{U} / \mathrm{L}$ and Blood glucose $>99 \mathrm{mg} \%$ & $1(2 \%)$ & $1(2 \%)$ & 1.001 \\
\hline
\end{tabular}


Tabela 6. Consistency and sensitivity of the liver in relation to the liver function tests in aged and non-aged alcoholics

\begin{tabular}{|c|c|c|c|c|c|c|}
\hline & \multicolumn{2}{|c|}{ Aged \# } & \multicolumn{2}{|c|}{ Non-aged \# \# } & & \\
\hline & \multicolumn{2}{|c|}{$\geq 60$ years } & \multicolumn{2}{|c|}{$<60$ years } & \multirow{3}{*}{$\begin{array}{c}\mathrm{p} \\
\text { Albumin }\end{array}$} & \multirow[b]{3}{*}{ Bilirubin } \\
\hline & \multicolumn{2}{|c|}{ n. 50} & \multicolumn{2}{|c|}{ n. 50} & & \\
\hline & Albumin & Bilirubin & Albumin & Bilirubin $\sum$ & & \\
\hline & $\leq 3.5 \mathrm{~g} \%$ & $>1.2 \mathrm{mg} \%$ & $\leq 3.5 \mathrm{mg} \%$ & $>1.2 \mathrm{mg} \%$ & & \\
\hline Liver palpable & $23(46 \%) *$ & $7(14 \%)^{€}$ & $18(36 \%) *$ & $12(24 \%)^{€}$ & 0.416 & 0.300 \\
\hline Liver not palpable & 12 (24\%) & $5(10 \%)$ & $4(8 \%)$ & $3(6 \%)$ & 0.056 & 1.000 \\
\hline \multirow[t]{2}{*}{ Total } & $35(70 \%)$ & $12(24 \%)$ & $22(44 \%)$ & $15(30 \%)$ & $0.026 \#$ & 0.683 \# \\
\hline & & & & & 0.001 \#\# & $0.003 \# \#$ \\
\hline \multicolumn{7}{|c|}{$\begin{array}{l}\text { Consistence and Sensitivity } \\
\text { of the liver }\end{array}$} \\
\hline Soft not painful & $4(8 \%)$ & $1(2 \%)$ & $1(2 \%)$ & $1(2 \%)$ & 0.504 & 0.714 \\
\hline Soft painful & - & - & $1(2 \%)$ & $1(2 \%)$ & - & - \\
\hline Firm not painful & $18(36 \%) * *$ & $5(10 \%)$ & $13(26 \%) * *$ & 7 (14\%) & 0.002 & 0.002 \\
\hline Firm painful & $1(2 \%)$ & $1(2 \%)$ & $3(6 \%)$ & $3(6 \%)$ & 0.430 & 0.976 \\
\hline
\end{tabular}

\# Aged \#\# Non-aged $\sum$ Total bilirubin p Albumin p Bilirubin

In both groups, the prevalence of hypoalbuminemia was significantly higher when the liver was palpable * than non-palpable (p: 0.026 and 0.001 , respectively). The prevalence of significantly elevated bilirubin only occurred among patients with palpable liver of the non-aged group $(\mathrm{p}=0.003)$. In both groups, the prevalence of firm not painful liver ** was significantly higher than the other characteristics of consistence and sensitivity hepatic

Table 7. Serologic conditions and prevalence of tattooing in the aged and non-aged alcoholics

\begin{tabular}{lcc}
\hline & Aged & Non-aged \\
\hline & 50 & 50 \\
Hepatitis B virus surface antigen & $0-$ & $0-$ \\
Antibody anti-hepatitis C virus & $1(2 \%)$ & $2(4 \%)$ \\
Antibody anti-HIV & $1(2 \%)$ & $0-$ \\
VDRL & $3(6 \%)$ & $2(4 \%)$ \\
Tattooing & $3(6 \%)$ & $6(12 \%)$ \\
\hline
\end{tabular}

